\title{
Association between CAG repeat polymorphisms and the risk of prostate cancer: A meta-analysis by race, study design and the number of (CAG)n repeat polymorphisms
}

\author{
JUN-HYUN SUN and SANG-AH LEE \\ Department of Preventive Medicine, Kangwon National University School of Medicine, \\ Chuncheon-si, Gangwon-do 200-701, Republic of Korea
}

Received May 28, 2013; Accepted July 29, 2013

DOI: $10.3892 /$ ijmm.2013.1474

\begin{abstract}
Although a number of studies have been conducted on the association between prostate cancer and CAG repeat polymorphisms of the androgen receptor gene, this association remains elusive and controversial. In this meta-analysis, we aimed to evaluate the effects of (CAG)n repeat genetic polymorphisms on the incidence of prostate cancer, particularly as regards race, study design and the number of (CAG)n repeats. To collect articles published on the association between CAG repeats and prostate cancer, publications were identified from the National Center for Biotechnology Information (NCBI) database of epidemiological studies published up to October 2011; our identification of publications was not limited by a language barrier. The following search keywords were used: prostate cancer risk, CAG repeat polymorphism, androgen receptor gene and human. Stata version 10 was used for the meta-analysis and the publication bias was measured through the Begg's test and Egger's test. This meta-analysis included 47 studies with 13,346 cases and 15,172 control or non-cases and consisted of 31 reports based on Caucasians, ten on Asians, one on Hispanics and four on combined ethnic groups. The carriers of a shorter CAG repeat sequence had an increased risk of prostate cancer (OR 1.21, 95\% CI 1.10-1.34 for all subjects; OR 1.21, 95\% CI 1.10-1.34 for prospective studies; OR 1.32, 95\% CI 1.15-1.51 for retrospective studies) regardless of the exact length of the CAG repeat, compared with carriers of a longer repeat sequence. In terms of race, the risk of carrying a shorter CAG repeat sequence was 1.10- and 1.83-fold higher than that of a longer repeat sequence in Caucasians and Asians,
\end{abstract}

Correspondence to: Professor Sang-Ah Lee, Department of Preventive Medicine, Kangwon National University School of Medicine, 1 Kangwondaehak-gil, Chuncheon-si, Gangwon-do 200-701, Republic of Korea

E-mail: sangahlee@kangwon.ac.kr

Key words: prostate cancer, CAG repeat, androgen receptor, meta-analysis respectively. For the specific number of CAG repeat polymorphisms, carriers of $<22$ repeats were observed to have a higher risk of prostate cancer (OR 1.16, 95\% CI 1.04-1.29) compared with carriers with $\geq 22$ CAG repeat polymorphisms, particularly for Asians (OR 2.06, 95\% CI 1.00-4.24). This meta-analysis suggests that a shorter CAG repeat polymorphism may increase the risk of prostate cancer compared with the longer CAG repeat; in particular, the effect of shorter CAG repeats on the increased risk of prostate cancer was predominantly observed in Caucasians and Asians.

\section{Introduction}

Prostate cancer is ranked as the second major cause of cancer-related mortality in developed countries (1). Although the incidence of latent prostate cancer appears to be constant worldwide, the incidence of its clinical forms varies substantially (2). African-American males have long been known to have the highest rates of prostate cancer worldwide, whereas native Japanese and Chinese males have the lowest known prostate cancer rates (3). This difference is likely due to both environmental and genetic factors. In addition to the role of age and race on the risk of prostate cancer, family history appears to be one of the most important risk factors (4): the incidence of prostate cancer is positively associated with relevant family history with a strong genetic dose-effect (5).

Androgen plays an important role in the growth and functions of both normal and malignant prostate glands and can affect the carcinogenesis of prostate cancer (3). Androgen function is achieved by the androgen receptor, which is a ligand-dependent nuclear transcription factor $(6,7)$. Dihydrotestosterone, transformer of testosterone, combines with the carboxyl-terminal of an androgen receptor, which is activated and changed into a form with greater structural stability. Subsequently, it enters the nucleus to combine with the androgen response elements (AREs) in the DNA to induce transcription (8). The androgen receptor gene is located on chromosome Xq11-12 and is composed of eight exons. These eight exons each perform in the transcription of the amino-terminal transcriptional activation (transactivation) domain, the DNA binding domain (a hinge region) and the carboxyl-terminal ligand binding domain. Among these three 
domains, the transactivation domain has several polymorphisms, which regulate the manifestation of the target gene. Three microsatellite trinucleotide repeats exist in this transactivation domain. In particular, CAG presents with a different length for each person and exists upstream and downstream of each domain to encode polyglutamine and polyglycine (9). An experimental study discovered that the replication of the androgen receptor gene within prostate epithelial cells was increased with a shorter CAG repeat (10).

The average CAG repeat length has a wide ethnic variety: Africans possess a slightly shorter CAG repeats than Caucasians, whereas Asians have a longer CAG repeat than other races. In general, the CAG repeat length is measured as 19,22 and 23 for Africans, Caucasians and Asians, respectively (11). Therefore, in this meta-analysis, we aimed to evaluate the effects of (CAG) $\mathrm{n}$ repeat polymorphisms of the androgen receptor gene in relation to the risk of prostate cancer, as regards race and the number of CAG repeat polymorphisms simultaneously, as well as the characteristics of the study design.

\section{Materials and methods}

Search strategy. To collect articles published on the association between CAG repeats and prostate cancer, publications were identified from the National Center for Biotechnology Information (NCBI) database of epidemiological studies. The following keywords were used: prostate cancer risk, CAG repeat polymorphism, androgen receptor gene and human. We further examined citations for all retrieved articles of studies that had not been initially identified. If more than one geographical or ethnic population was included, we considered each population or group independently.

We identified studies that fulfilled the following criteria: i) evaluation of the association between prostate cancer and CAG repeat polymorphisms; ii) nested case-control, case-control or cross-sectional study; and iii) sufficient information on CAG repeat distributions between patients and controls for estimating the odds ratio (OR) and the $95 \%$ confidence interval $(95 \% \mathrm{CI})$.

Data extraction. The two authors of this article independently extracted the following information from all available studies. Original studies were blinded for authors, affiliations, journal names, publication year and acknowledgments. Each study was categorized as one of the following items: general information (publication year and geographical area), population characteristics (size of the study, population and ethnicity) and patient and control subject characteristics (number, mean age at diagnosis and their respective status in terms of to what extent the prostate cancer of the subject had progressed). To investigate the potential influence of the timing of diagnosis, all studies were classified as either prospective (cohort) studies or retrospective (case-control and cross-sectional) studies. For stratified analysis by ethnicity, each article was classified into Caucasians, Asians and Africans based on the respective number of participants, apart from one study on Hispanics. If the results of various races were included in one report, the results of each race were separately used during the subgroup analysis. Finally, 47 studies were included in this meta-analysis (13-18,23-24,30-68).
For each study, we extracted an OR to evaluate the risk of CAG repeat polymorphisms in relation to the risk of prostate cancer. If the OR was not presented, but the number of case and controls were reported, we calculated the OR. We analyzed 47 studies by using shorter/longer repeats presented in each article regardless of the exact cut-off length of the CAG repeat. In addition, we focused on two widely evaluated dichotomous comparisons, viz. $\geq 23$ repeats of the CAG sequence vs. others and $\geq 22$ repeats vs. others. This was done as no studies provided the specific distributions of the repeat counts.

Statistical analysis. The strength of the association between the cut-off values of the repeat number and the risk of prostate cancer was assessed by calculating the OR and the $95 \%$ CI. In this meta-analysis, we used the random-effects model instead of the fixed-effects model. Estimates were also stratified by study design (prospective vs. retrospective), the CAG repeat polymorphism (shorter vs. longer) and ethnicity (Caucasian vs. Asian vs. African). The effect, standard error and variability were measured for the heterogeneity test in accordance with the $\log$ OR and calculated through function Meta. In addition, meta-regression was employed to estimate the covariates which could explain the heterogeneity.

The heterogeneity between the studies was presented through the random effects model. The between-study heterogeneity was assessed by the $\chi^{2}$ test-based Q statistic. A P-value $<0.05$ was considered to indicate a statistically significant difference. A meta-regression was conducted to identify sources of between-study heterogeneity.

An estimate of potential publication bias was carried out by the funnel plot and Egger's linear regression test (69). The potential publication bias was examined visually in a funnel plot of log (OR) against its standard error (SE) and the degree of asymmetry was tested by Egger's test $(\mathrm{P}<0.05$ was considered a significant publication bias). Begg's test (70) and Egger's test can detect funnel plot asymmetry by determining whether the intercept deviates significantly from zero in a regression of the standardized effect estimates against their precision. If publication bias existed, the non-parametric 'trim and fill' method was used to adjust for it (71). We predicted the contribution of the CAG repeat polymorphism to the risk of prostate cancer using Stata software version 10.0.

\section{Results}

After an extensive literature search, we finally identified 47 reports that satisfied our inclusion/exclusion criteria and conducted at least one of the aforementioned comparisons. Our search and selection process is described in Fig. 1. The selected literature included nine nested case-control studies, 31 case-control studies and seven cross-sectional studies. We focused on two widely evaluated dichotomous comparisons: as considering overlap, 16 and 27 studies reported the comparison of $\geq 23$ repeats of CAG sequences vs. others and $\geq 22$ repeats vs. others, respectively. Studies were classified according to race: 31 reports on Caucasians, ten on Asians, six on Africans, one on Hispanics and four on mixed race subjects.

In total, there were 47 reports with 13,346 patients and 15,172 controls. A total of 11 studies were selected from seven Asian countries (including Japan, China, Singapore, India, 


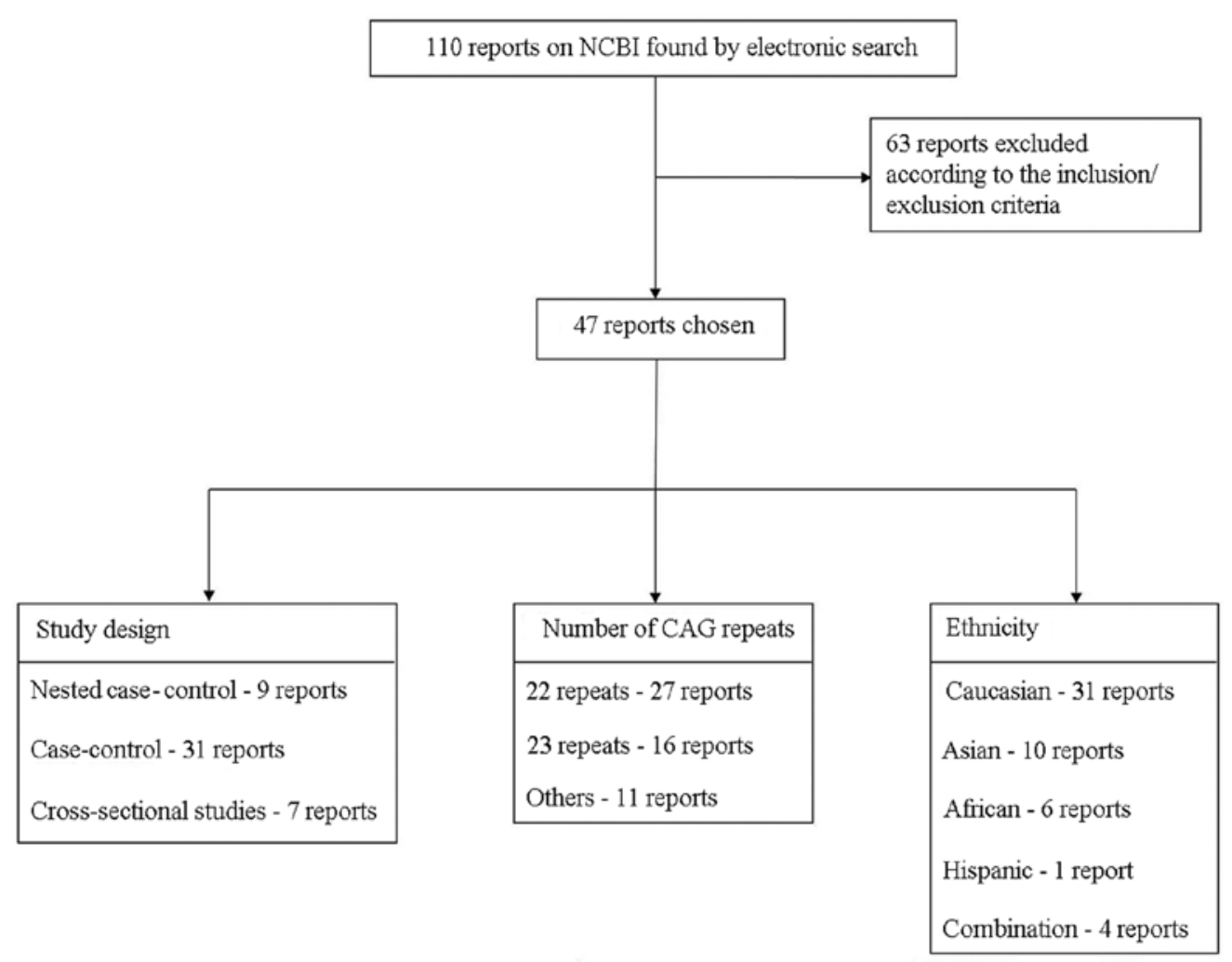

Figure 1. Diagram of the literature search and selection process. Cross-sectional studies were included in case-control studies when conducting analysis according to the study design. Others: $<17 / \geq 17,<18 / \geq 18,<19 / \geq 19,<20 / \geq 20,<21 / \geq 21,<25 / \geq 25$.

Taiwan, Iran and Israel), 36 studies were selected from nine Western countries (including the USA, Austria, Israel, France, Sweden, Finland, Germany, England and Italy) and seven studies were selected from Brazil, South Africa, Nigeria and Colombia. The age range was from 45 to 76.2 years for the patient group and from 45 to 75 years for the control group. The pathological stage of prostate cancer was presented in 21 reports among the selected literature (Table I).

The carriers of a shorter CAG repeat had an increased risk of prostate cancer (OR 1.21, 95\% CI 1.10-1.34) compared with those of a longer CAG repeat based on the presented criteria taken from the original study whatever the exact length of the CAG repeat (Fig. 2). Most prospective studies showed no significant differences between shorter and longer repeats, apart from one report. Therefore, the results of the meta-analysis in relation to the prospective studies did not indicate the association of shorter CAG repeats with the risk of prostate cancer risk (OR 1.04, 95\% CI 0.90-1.20). In terms of retrospective studies, 14 studies out of 31 reports presented a higher risk of shorter CAG repeats compared with longer CAG repeats (OR 1.32, 95\% CI 1.15-1.51).

On the other hand, the effect of shorter CAG repeats on the incidence of prostate cancer was predominant among Asians (OR 1.83, 95\% CI 1.04-3.22, Table II); the results for Caucasians indicated borderline significance (OR 1.12, 95\% CI 0.99-1.26) and there was no significant difference between the CAG repeat polymorphisms and prostate cancer risk among Africans (OR 0.87, 95\% CI 0.35-2.17). Based on the specific repeat number of CAG polymorphisms, we carried out an advanced analysis following stratification by race and the number of CAG repeats (Table II). Based on the meta-analysis of 27 studies, which presented the association between the $\geq 22$ CAG repeat polymorphisms and the risk of prostate cancer, we observed a positive association of $<22$ CAG repeat polymorphisms with the risk of cancer $(\mathrm{OR}=1.16,95 \% \mathrm{CI} 1.04-1.29)$. In particular, the risk increased by 2.06-fold in Asians (OR 2.06, 95\% CI 1.00-4.24), but not in Caucasians (OR 1.07,95\% CI 0.98-1.18) and Africans (OR 0.95, 95\% CI 0.53-1.70). On the other hand, there was no association of the $<23$ CAG repeat polymorphisms with the risk of prostate cancer using 16 studies compared with $\geq 23$ CAG repeats. In the analysis conducted according to race, no difference was presented between longer CAG repeats and shorter CAG repeats in terms of the risk of prostate cancer (Table II).

Publication bias was analyzed according to the study design (Fig. 3). For the prospective studies, the P-value was 0.53 for Begg's test and 0.41 for Egger's test, and no publication bias was identified. For the retrospective studies, we found a publication bias (both Begg's and Egger's test was 0.03 ). Five retrospective studies contributed to the publication bias based on the deviability from the standard $(19,39,43,49,67)$. Publication bias was observed according to race. For Caucasians, the P-value was 0.07 for Begg's test and 0.03 for Egger's test. For Asians, the P-value was 0.79 for Begg's test and 0.96 for Egger's test. For Africans, the P-value was 0.85 for Begg's test and 0.99 for Egger's test. A statistical significance in terms of the heterogeneity between the 47 studies was observed $(\mathrm{Q}=196.18 ; \mathrm{P}=0.00)$. 
Table I. Characteristics of published epidemiological studies concerning the association between the length of CAG repeat polymorphisms and the risk of prostate cancer.

\begin{tabular}{|c|c|c|c|c|c|c|c|c|c|}
\hline \multirow[b]{2}{*}{ Authors (Refs.) } & \multicolumn{2}{|c|}{ Population } & \multirow{2}{*}{$\begin{array}{l}\text { No. of subject } \\
\text { case/control }\end{array}$} & \multicolumn{2}{|c|}{ Age } & \multirow{2}{*}{$\begin{array}{c}\text { Case } \\
\text { Ad. }(\%)\end{array}$} & \multirow{2}{*}{\multicolumn{3}{|c|}{$\begin{array}{l}\text { Cut-off point o } \\
\text { repeat no. }{ }^{a}\end{array}$}} \\
\hline & Ethnicity & Country & & Case & Control & & & & \\
\hline \multicolumn{10}{|l|}{ Prospective studies } \\
\hline Lange et al (26) & Afr & USA & $131 / 340$ & 67.0 & 62.1 & - & 22 & 23 & \\
\hline Platz et al (27) & $\mathrm{C}$ & USA & $448 / 448$ & 69.8 & - & - & 22 & & \\
\hline Freedman et al (28) & $A+A f r+C+L$ & USA & $2036 / 2160$ & 60.0 & 60.0 & - & 22 & & 23 \\
\hline Visvanathan et al (29) & $\mathrm{C}$ & USA & $164 / 324$ & 66.1 & 66.0 & - & 22 & & \\
\hline Chen et al (30) & $\mathrm{C}$ & USA & $300 / 300$ & 61.2 & 60.8 & 11.5 & 22 & & \\
\hline Latil et al (31) & $\mathrm{C}$ & France & $226 / 156$ & 70.5 & 71.7 & 69.8 & & 23 & \\
\hline Platz et al (32) & $\mathrm{C}$ & USA & $582 / 794$ & 62.0 & - & 46.6 & & & 20 \\
\hline Giovannucci et al (18) & $\mathrm{C}$ & USA & $587 / 588$ & - & - & 30.7 & 22 & & \\
\hline \multirow[t]{2}{*}{ Price et al (33) } & Afr & USA & $116 / 149$ & 63.4 & 63.6 & - & & & 19 \\
\hline & $\mathrm{C}$ & USA & $1076 / 1047$ & 63.4 & 63.6 & - & & & \\
\hline \multicolumn{10}{|l|}{ Retrospective studies } \\
\hline Nicolaiew et al (34) & $\mathrm{C}$ & French & $1045 / 814$ & 67.0 & 63.0 & - & & & 17 \\
\hline Silva et al (35) & $\mathrm{C}+\mathrm{U}$ & Brazil & $49 / 51$ & 64.0 & 59.3 & - & 22 & & \\
\hline Das et al (36) & A & Singapore & $52 / 46$ & 66.0 & 69.0 & - & & & 23 \\
\hline Andersson et al (24) & $\mathrm{C}$ & Sweden & $137 / 125$ & 76.2 & 60.0 & - & & 23 & \\
\hline Lindström et al (37) & $\mathrm{C}$ & Sweden & $1461 / 796$ & - & - & 48.0 & & 23 & \\
\hline Okugi et al (38) & A & Japan & $102 / 117$ & 69.9 & 71.0 & 55.8 & & 23 & \\
\hline Krishnaswamy et al (39) & A & india & $87 / 120$ & 67.5 & 66.5 & - & & & 20 \\
\hline Sieh et al (40) & $\mathrm{Afr}+\mathrm{C}$ & USA & $193 / 391$ & 76.7 & 72.9 & 34.2 & 22 & & \\
\hline Salinas et al (41) & $\mathrm{C}$ & USA & $591 / 538$ & 57.3 & 56.8 & - & 22 & & \\
\hline Forrest et al (42) & $\mathrm{C}$ & UK & $50 / 76$ & 51.1 & - & - & & & 23 \\
\hline Mishra et al (43) & A & india & $113 / 133$ & 65.6 & 63.7 & - & & 23 & 20 \\
\hline \multirow[t]{2}{*}{ Cicek et al (44) } & $\mathrm{C}$ & USA & $397 / 397$ & 63.0 & 63.0 & - & 22 & & \\
\hline & Afr & USA & $38 / 38$ & 62.0 & 63.0 & - & & & \\
\hline Gilligan et al (45) & Afr & Columbia & $118 / 567$ & 66.7 & 55.5 & 24.5 & 22 & & \\
\hline Huang et al (46) & A & Taiwan & $66 / 104$ & 71.5 & 71.7 & 40.9 & & 23 & \\
\hline Gsur et al (47) & $\mathrm{C}$ & Austria & 190/190 & 65.9 & 66.5 & - & & 23 & \\
\hline Mononen et al (48) & $\mathrm{C}$ & Finland & $461 / 574$ & 68.1 & - & 48.1 & & & 19,25 \\
\hline Balic et al (49) & $\mathrm{H}$ & USA & $82 / 145$ & 64.0 & 57.0 & & & & 19 \\
\hline Modugno et al (50) & $\mathrm{C}$ & USA & $88 / 241$ & 68.9 & 73.6 & - & & 23 & \\
\hline Xue et al (51) & $\mathrm{C}$ & USA & $57 / 156$ & 57.8 & - & - & & & 20 \\
\hline Lange et al (52) & $\mathrm{C}$ & USA & $133 / 305$ & 64.0 & & - & 22 & & \\
\hline Hsing et al (53) & A & China & $191 / 304$ & 72.2 & 71.9 & 62.6 & 22 & 23 & \\
\hline Correa-Cerro et al (54) & $\mathrm{C}$ & Fra./Ger. & $85 / 46$ & 68.2 & 71.2 & - & 22 & & \\
\hline Edwards et al (55) & $\mathrm{C}$ & UK & $178 / 195$ & 68.1 & - & 75.3 & 22 & & \\
\hline \multirow[t]{2}{*}{ Ekman et al (56) } & $\mathrm{C}$ & Sweden & $59 / 38$ & 69.0 & 72.0 & - & 22 & 23 & \\
\hline & A & Japan & $34 / 33$ & 71.0 & 60.0 & - & & & \\
\hline Ingles et al (57) & $\mathrm{C}$ & USA & $57 / 169$ & 57.8 & 58.2 & 46.0 & 22 & & \\
\hline Stanford et al (58) & $\mathrm{C}$ & USA & $301 / 277$ & 54.9 & 54.0 & 45.9 & 22 & & \\
\hline Hakimi et al (19) & $\mathrm{C}$ & USA & $59 / 370$ & 62.1 & - & 42.4 & & & 18 \\
\hline \multirow[t]{2}{*}{ Li et al (59) } & A & Japan & $33 / 43$ & 33.0 & - & 75.0 & 22 & 23 & \\
\hline & $\mathrm{C}$ & Sweden & $59 / 98$ & 59.0 & - & 50.4 & & & \\
\hline Kuasne et al (60) & $\mathrm{C}$ & Brazil & $160 / 160$ & 65.4 & 63.9 & - & & & 21 \\
\hline Ashtiani et al (61) & A & Iran & $110 / 67$ & 69.5 & 60.4 & - & 22 & & \\
\hline Akinloye et al (62) & Afr & Nigeria & $70 / 73$ & 63.5 & 62.3 & - & 22 & & \\
\hline Chang et al (63) & $\mathrm{C}$ & USA & $245 / 222$ & 60.9 & 58.0 & - & 22 & & \\
\hline Miller et al (64) & $\mathrm{C}$ & USA & $137 / 69$ & 65.7 & 66.2 & - & 22 & & \\
\hline Irvine et al (65) & $\mathrm{C}$ & USA & $57 / 39$ & 57.7 & 35.0 & 47.0 & 22 & & \\
\hline
\end{tabular}


Table I. Continued.

\begin{tabular}{|c|c|c|c|c|c|c|c|c|}
\hline \multirow{3}{*}{$\frac{\text { Author (Refs.) }}{\text { Panz et al (66) }}$} & \multicolumn{2}{|c|}{ Population } & \multirow{2}{*}{$\begin{array}{l}\text { No. of subject } \\
\text { case/control }\end{array}$} & \multicolumn{2}{|c|}{ Age } & \multirow{2}{*}{$\begin{array}{l}\text { Case } \\
\text { Ad. }(\%)\end{array}$} & \multirow{2}{*}{\multicolumn{2}{|c|}{$\begin{array}{l}\text { Cut-off point o } \\
\text { repeat no. }\end{array}$}} \\
\hline & \multirow{3}{*}{$\begin{array}{c}\text { Ethnicity } \\
\mathrm{C} \\
\text { Afr }\end{array}$} & \multirow{3}{*}{\begin{tabular}{l}
\multicolumn{1}{c}{ Country } \\
USA \\
Israel/ \\
South Africa
\end{tabular}} & & \multirow{2}{*}{$\begin{array}{l}\text { Case } \\
68.0\end{array}$} & \multirow{2}{*}{$\begin{array}{c}\text { Control } \\
-\end{array}$} & & & \\
\hline & & & $20 / 20$ & & & 30.0 & 22 & 23 \\
\hline & & & $20 / 20$ & 76.0 & - & 30.0 & & \\
\hline Mittal et al (67) & A & India & $135 / 142$ & 66.2 & 64.1 & - & 22 & \\
\hline Santos et al (68) & $A+A f r+C$ & Brazil & $133 / 279$ & 65.0 & 58.0 & - & 22 & \\
\hline Risio et al (12) & $\mathrm{C}$ & Italy & $69 / 234$ & 65 & 62.5 & 24.2 & & 21 \\
\hline
\end{tabular}

Ad. (\%), percentage of advanced prostate cancer. That is T3-T4, M0; T0-T4, M1. ${ }^{\mathrm{a} E a c h}$ number indicates the cut-off point for CAG repeat polymorphisms. A, Asian; Afr, African; C, Caucasian; L, Latino; H, Hispanic; U, unknown; UK, United Kingdom; Fra., France; Ger., Germany.

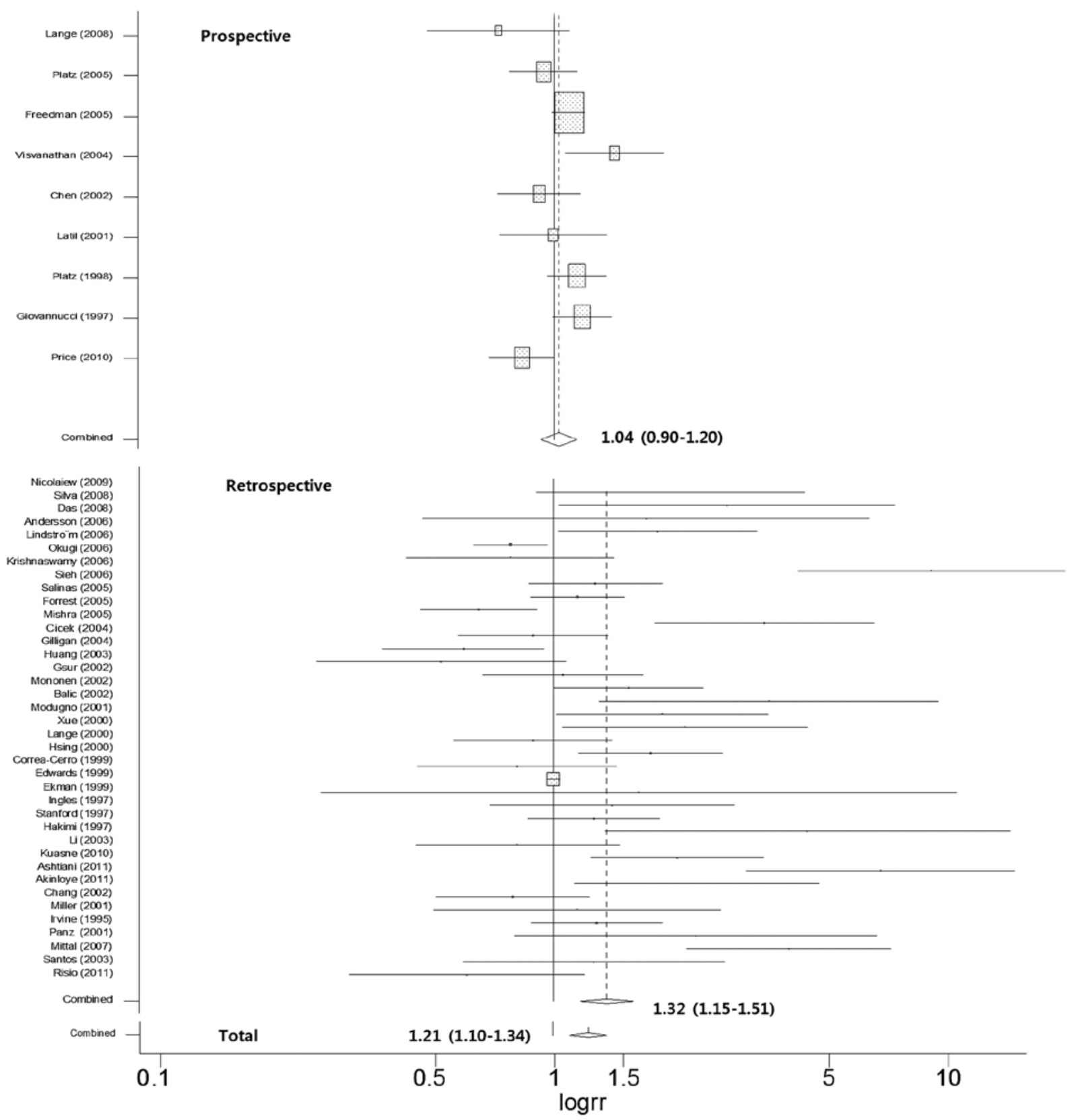

Figure 2. Study-specific estimates (boxes) and corresponding 95\% CI (horizontal lines) for the effect of CAG repeat polymorphisms on the risk of prostate cancer. (Q=196.18, $\mathrm{P}=0.00)$. 


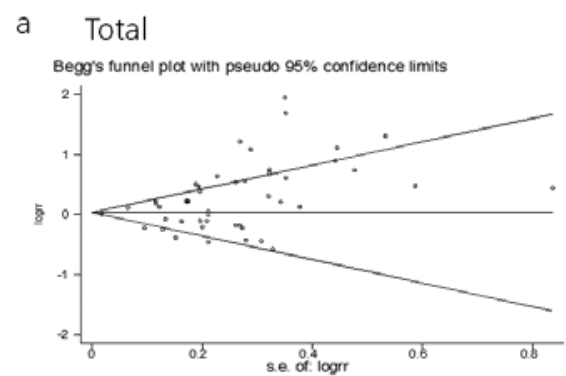

Begg's test- 0.03 Egger's test- 0.004

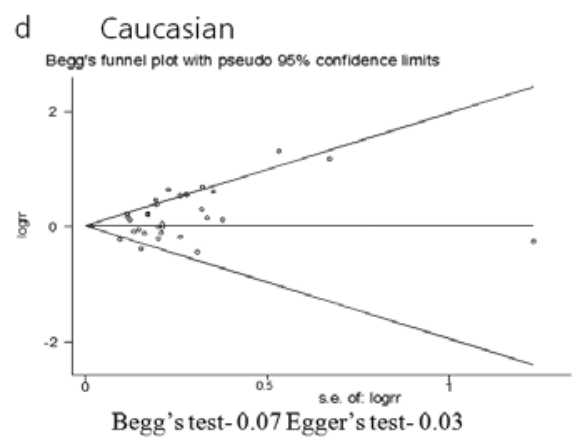

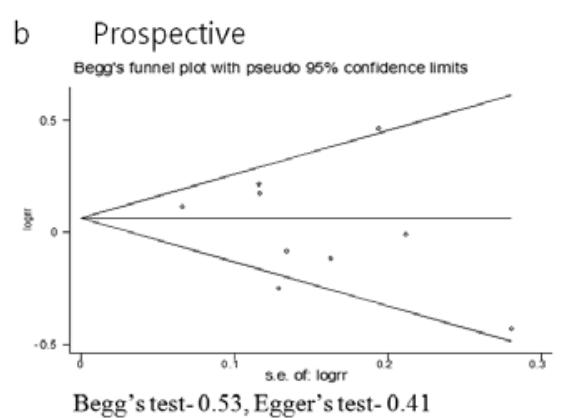

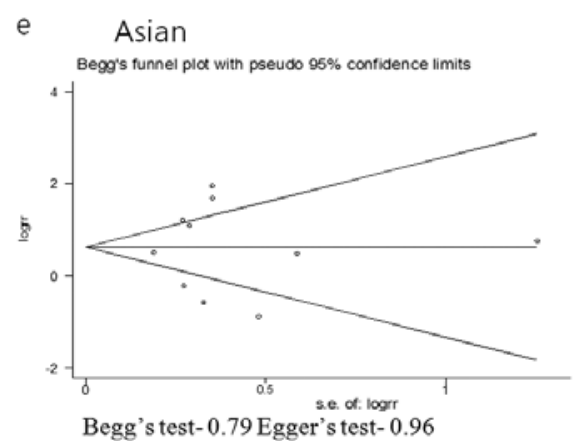

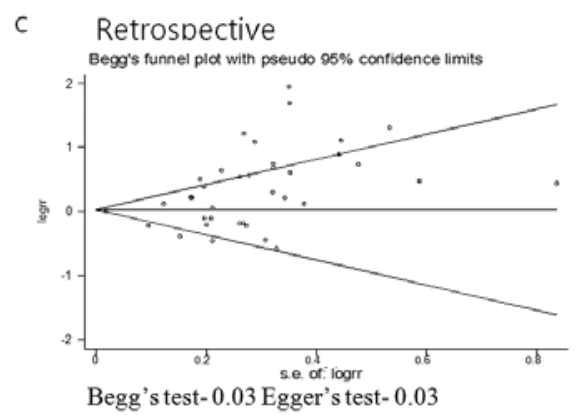

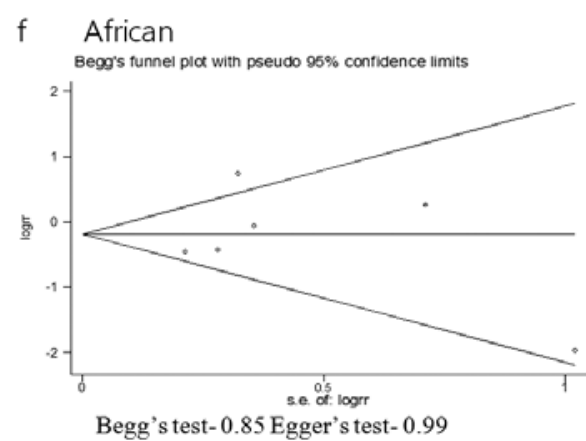

Figure 3. Publication bias plot for CAG repeat polymorphisms.

\section{Discussion}

The results of this meta-analysis of 13,346 patients and 15,172 controls from 47 reports suggest that shorter CAG repeat polymorphisms of the androgen receptors are associated with the increased risk of prostate cancer compared with longer CAG repeats regardless of the exact number of CAG repeat polymorphisms. The association was not shown in the meta-analysis using prospective studies, but was observed using retrospective studies. In particular, while the risk of prostate cancer increased predominately among Asians, this was not the case among Africans and Caucasians. Considering the number of CAG repeat polymorphisms, the association was only presented after stratification by dichotomous comparison viz. <22 CAG repeats of CAG polymorphisms vs. others.

Although the majority of studies report a positive association between shorter CAG repeat polymorphisms and the risk of prostate cancer, the cut-off point for the length of CAG repeats differed from each race and study population. The length of a CAG repeat was usually longer in Asians than in Caucasians (12). In general, the majority of studies may have taken the average CAG repeat as the cut-off point for the CAG repeats. Therefore, it is difficult to take a unique and standard cut-off point of the CAG repeat polymorphisms for a meta-analysis. In our meta-analysis, the effect of the shorter CAG repeat polymorphisms on the increased risk of prostate cancer was evaluated using shorter and longer CAG repeats whatever the exact cut-off point of the CAG repeat length in each of the 47 studies. A meta-analysis with 23 studies published in 2004 (13) suggested that prostate cancer patients have a short CAG repeat length (the average difference between cases and controls was 0.26 ) and reported that the incidence rate of prostate cancer decreased to 1.02 with the increase of one CAG repeat. Another meta-analysis conducted in 2012 (14) was based on 27 studies and reported that the risk decreased by 0.79 -fold among subjects aged 45 years and above when the cut-off point of the CAG repeats was taken as $<21$ vs. $\geq 21$ CAG repeat polymorphisms. On the other hand, a recent and major prospective study in the USA (15) reported no association between the CAG repeat and the risk of prostate cancer based on a continuous model (OR 0.96, 95\% CI 0.88-1.08, $\mathrm{P}($ trend $)=0.46$, per $10 \mathrm{CAG}$ repeat increment). However, this study did not examine the effect of the CAG repeat polymorphisms in terms of shorter vs. longer.

Testosterone combines with androgen receptors to stabilize the structure and promote the replication of androgen receptors associated with prostate cancer. The testosterone level of African-Americans was $15 \%$ higher than that of European-Americans, which may explain the difference in the incidence of prostate cancer between the two ethnic groups (16). An experimental study discovered that the increased transcription of the androgen receptor gene within prostate epithelial cells was associated with shorter CAG repeats (17). Certain studies have suggested that short CAG repeats constantly stimulate androgen, which gives rise to the proliferation of prostate cells and finally induces somatic mutation $(6,18)$. Furthermore, short $\mathrm{CAG}$ repeats have been associated with the aggressive forms of prostate cancer, as well as the incidence of other androgen-related diseases $(18,19)$. The decreased formation and fertilization of sperm cased by longer CAG repeats (20), balding (21) and prostatic hypertrophy $(22,23)$ have been associated with shorter CAG repeats. Andersson et al suggested two possible mechanisms to explain the association between the length of CAG repeat polymorphisms and androgen receptor transcription. First, the trinucleotide CAG repeat may act as a suppressor of transactivation, where the longer length of the triple region acts as a more effective suppressor. Second, a receptor with a shorter CAG repeat has a more stable structure (24). 
Table II. Association of CAG repeat polymorphisms with the risk of prostate cancer following stratification by study design, cut-off point for repeat number and ethnicity.

\begin{tabular}{|c|c|c|}
\hline & Refs. & Meta-analysis (OR) \\
\hline \multicolumn{3}{|l|}{ Overall } \\
\hline Shorter/ longer & (47) & $1.21(1.10-1.34)$ \\
\hline \multicolumn{3}{|l|}{ Subgroup } \\
\hline \multicolumn{3}{|l|}{ Study design } \\
\hline \multicolumn{3}{|l|}{ Prospective } \\
\hline All & (9) & $1.04(0.90-1.20)$ \\
\hline Caucasian & (7) & $1.09(0.95-1.25)$ \\
\hline African & (2) & $0.75(0.49-1.15)$ \\
\hline \multicolumn{3}{|l|}{ Retrospective } \\
\hline All & $(38)$ & $1.32(1.15-1.51)$ \\
\hline Caucasian & (24) & $1.12(0.99-1.26)$ \\
\hline Asian & (10) & $1.83(1.04-3.22)$ \\
\hline African & (4) & $0.87(0.35-2.17)$ \\
\hline \multicolumn{3}{|l|}{$\begin{array}{l}\text { Length of CAG } \\
\text { repeat no. }\end{array}$} \\
\hline $\begin{array}{l}\text { repeat no. } \\
<22 / \geq 22\end{array}$ & (27) & $1.16(1.04-1.29)$ \\
\hline$<23 / \geq 23$ & (16) & $1.09(0.90-1.33)$ \\
\hline \multicolumn{3}{|l|}{ Ethnicity } \\
\hline \multicolumn{3}{|l|}{ Caucasian } \\
\hline All & $(31)$ & $1.10(1.00-1.21)$ \\
\hline$<22 / \geq 22$ & (17) & $1.07(0.98-1.18)$ \\
\hline$<23 / \geq 23$ & (9) & $1.07(0.83-1.39)$ \\
\hline \multicolumn{3}{|l|}{ Asian } \\
\hline All & (10) & $1.83(1.04-3.22)$ \\
\hline$<22 / \geq 22$ & (5) & $2.06(1.00-4.24)$ \\
\hline$<23 / \geq 23$ & (7) & $1.16(0.65-2.00)$ \\
\hline \multicolumn{3}{|l|}{ African } \\
\hline All & (6) & $0.86(0.52-1.43)$ \\
\hline$<22 / \geq 22$ & (5) & $0.95(0.53-1.70)$ \\
\hline$<23 / \geq 23$ & (2) & $0.71(0.43-1.19)$ \\
\hline
\end{tabular}

The average CAG repeat length has a wide ethnic variety (11). Africans possess a slightly shorter CAG repeat than Caucasians, whereas Asians have a longer CAG repeat than subjects from other races. In general, the length of the CAG repeat was measured respectively as 19, 22 and 23 for Africans, Caucasian and Asians (11). The risk of prostate cancer generally increases in Western countries but decreases in Asian countries (3). This suggests that there is a clear association of the CAG repeat polymorphisms with the risk of prostate cancer (25). Our meta-analysis also presents the protective effect of longer CAG repeat polymorphisms on prostate cancer in Caucasians and Asians; the cut-off point of criteria for the meta-analysis was 22 and 23 for Caucasians and Asians, respectively. Although shorter CAG repeats were associated with a higher risk of prostate cancer than longer CAG repeats in case-control studies, no significant results were observed in nested case-control studies. The results of Caucasians and Asians in case-control studies were identical. Otherwise, the significance was still not observed in the analysis of nested case-control studies following stratification by race. Therefore, we should carefully explain the difference by race, as the association may not be independent of study design or the number of CAG repeats.

The strength of this meta-analysis is its large number of subjects, including 13,346 cases and 15,172 controls based on 47 studies (nine nested case-control studies, 31 case-control studies and seven cross-sectional studies). A meta-analysis conducted in 2004 composed of 4,274 cases and 5,275 controls and quoted a total of 23 studies: five nested case-control studies and 19 case-control studies (13). Another meta-analysis (14), which reported the association between androgen receptor CAG repeat polymorphisms with $\geq 22$ repeats and the risk of prostate cancer among subjects aged 45 years or older, was composed of 3,835 cases and 4,774 controls and only quoted a total of 27 studies. Furthermore, in the present meta-analysis, an advanced analysis was conducted according to study design, race and the number of CAG repeat polymorphisms, in contrast to previous meta-analysis reports.

However, this meta-analysis also had certain limitations. Confounding factors could not be used as we were unable to retrieve common information from all these original publications for a variety of confounding factors, such as smoking history or other lifestyle factors. Therefore, the findings from our meta-analysis require further confirmation or validation. On the other hand, the association between the risk of prostate cancer and androgen receptor CAG repeat polymorphisms was not observed in all races or studies. It is insufficient to explain the incidence of prostate cancer based on genetic factors only, as it does not correspond with the results of the genetic variation of previously presented studies. Individual differences in the sensitivity of prostate cancer cells must be explained in relation to other reasons, such as lifestyle (including smoking history and other environmental factors).

In conclusion, in this meta-analysis, it was verified that shorter CAG repeats increase the risk of prostate cancer compared with longer CAG repeats, whatever the exact length of the CAG repeat. In particular, race and the length of the CAG repeat polymorphisms may influence the association between the CAG repeat polymorphisms and the risk of prostate cancer.

\section{References}

1. Jemal A, Siegel R, Ward E, Murray T, Xu J, Smigal C and Thun MJ: Cancer statistics, 2006. CA Cancer J Clin 56: 106-130, 2006.

2. Parkin DM, Whelan SL, Ferlay J, Raymond and Young J (eds). Cancer incidence in five continents; Volume VII. IARC Sci Publ (143):i-xxxiv, 1-1240, Lyon 1997

3. Ross RK, Pike MC, Coetzee GA, Reichardt JK, Yu MC, Feigelson $\mathrm{H}$, et al: Androgen metabolism and prostate cancer: establishing a model of genetic susceptibility. Cancer Res 58: 4497-4504, 1998.

4. Zeegers MP, Jellema A and Ostrer H: Empiric risk of prostate carcinoma for relatives of patients with prostate carcinoma: a meta-analysis. Cancer 97: 1894-1903, 2003.

5. http://en.wikipedia.org/wiki/Prostate_cancer.

6. Nelson KA and Witte JS: Androgen receptor CAG repeats and prostate cancer. Am J Epidemiol 155: 883-890, 2002.

7. Wilding G: The importance of steroid hormones in prostate cancer. Cancer Surv 14: 113-130, 1992.

8. Crawford ED: Understanding the epidemiology, natural history, and key pathways involved in prostate cancer. Urology 73 (Suppl 5): S4-S10, 2009. 
9. Montgomery JS, Price DK and Figg WD: The androgen receptor gene and its influence on the development and progression of prostate cancer. J Pathol 195: 138-146, 2001.

10. Chamberlain NL, Driver ED and Miesfeld RL: The length and location of CAG trinucleotide repeats in the androgen receptor $\mathrm{N}$-terminal domain affect transactivation function. Nucleic Acids Res 22: 3181-3186, 1994.

11. Buchanan G, Yang M, Cheong A, Harris JM, Irvine RA, Lambert PF, et al: Structural and functional consequences of glutamine tract variation in the androgen receptor. Hum Mol Genet 13: 1677-1692, 2004.

12. Risio M, Venesio T, Kolomoets E, Armaroli P, Gallo F, Balsamo A, et al: Genetic polymorphisms of CYP17A1, vitamin D receptor and androgen receptor in Italian heredo-familial and sporadic prostate cancers. Cancer Epidemiol 35: e18-e24, 2011.

13. Zeegers MP, Kiemeney LA, Nieder AM and Ostrer H: How strong is the association between CAG and GGN repeat length polymorphisms in the androgen receptor gene and prostate cancer risk? Cancer Epidemiol Biomarkers Prev 13: 1765-1771, 2004.

14. Gu M, Dong X, Zhang X and Niu W: The CAG repeat polymorphism of androgen receptor gene and prostate cancer: a meta-analysis. Mol Biol Rep 39: 2615-2624, 2012.

15. Lindstrom S, Ma J, Altshuler D, Giovannucci E, Riboli E, Albanes D, et al: A large study of androgen receptor germline variants and their relation to sex hormone levels and prostate cancer risk. Results from the National Cancer Institute Breast and Prostate Cancer Cohort Consortium. J Clin Endocrinol Metab 95: E121-E127, 2010.

16. Ahluwalia B, Jackson MA, Jones GW, Williams AO, Rao MS and Rajguru S: Blood hormone profiles in prostate cancer patients in high-risk and low-risk populations. Cancer 48: 2267-2273, 1981.

17. Kazemi-Esfarjani P, Trifiro MA and Pinsky L: Evidence for a repressive function of the long polyglutamine tract in the human androgen receptor: possible pathogenetic relevance for the (CAG)n-expanded neuronopathies. Hum Mol Genet 4: 523-527, 1995.

18. Giovannucci E, Stampfer MJ, Krithivas K, Brown M, Dahl D, Brufsky A, et al: The CAG repeat within the androgen receptor gene and its relationship to prostate cancer. Proc Natl Acad Sci USA 94: 3320-3323, 1997.

19. Hakimi JM, Schoenberg MP, Rondinelli RH, Piantadosi S and Barrack ER: Androgen receptor variants with short glutamine or glycine repeats may identify unique subpopulations of men with prostate cancer. Clin Cancer Res 3: 1599-1608, 1997.

20. Yoshida KI, Yano M, Chiba K, Honda M and Kitahara S: CAG repeat length in the androgen receptor gene is enhanced in patients with idiopathic azoospermia. Urology 54: 1078-1081, 1999.

21. Sawaya ME and Shalita AR: Androgen receptor polymorphisms (CAG repeat lengths) in androgenetic alopecia, hirsutism, and acne. J Cutan Med Surg 3: 9-15, 1998.

22. Mitsumori K, Terai A, Oka H, Segawa T, Ogura K, Yoshida O and Ogawa O: Androgen receptor CAG repeat length polymorphism in benign prostatic hyperplasia (BPH): correlation with adenoma growth. Prostate 41: 253-257, 1999.

23. Shibata A, Stamey TA, McNeal JE, Cheng I and Peehl DM: Genetic polymorphisms in the androgen receptor and type II 5 alpha-reductase genes in prostate enlargement. J Urol 166 1560-1564, 2001.

24. Andersson P, Varenhorst E and Soderkvist P: Androgen receptor and vitamin $\mathrm{D}$ receptor gene polymorphisms and prostate cancer risk. Eur J Cancer 42: 2833-2837, 2006.

25. Sartor O, Zheng Q and Eastham JA: Androgen receptor gene CAG repeat length varies in a race-specific fashion in men without prostate cancer. Urology 53: 378-380, 1999.

26. Lange EM, Sarma AV, Ray A, Wang Y, Ho LA, Anderson SA, et al: The androgen receptor CAG and GGN repeat polymorphisms and prostate cancer susceptibility in African-American men: results from the Flint Men's Health Study. J Hum Genet 53: 220-226, 2008

27. Platz EA, Leitzmann MF, Rifai N, Kantoff PW, Chen YC, Stampfer MJ, et al: Sex steroid hormones and the androgen receptor gene CAG repeat and subsequent risk of prostate cancer in the prostate-specific antigen era. Cancer Epidemiol Biomarkers Prev 14: 1262-1269, 2005.

28. Freedman ML, Pearce CL, Penney KL, Hirschhorn JN, Kolonel LN, Henderson BE and Altshuler D: Systematic evaluation of genetic variation at the androgen receptor locus and risk of prostate cancer in a multiethnic cohort study. Am J Hum Genet 76: 82-90, 2005.
29. Visvanathan K, Helzlsouer KJ, Boorman DW, Strickland PT, Hoffman SC, Comstock GW, et al: Association among an ornithine decarboxylase polymorphism, androgen receptor gene (CAG) repeat length and prostate cancer risk. J Urol 171: 652-655, 2004.

30. Chen C, Lamharzi N, Weiss NS, Etzioni R, Dightman DA, Barnett M, et al: Androgen receptor polymorphisms and the incidence of prostate cancer. Cancer Epidemiol Biomarkers Prev 11: 1033-1040, 2002

31. Latil AG, Azzouzi R, Cancel GS, Guillaume EC, CochanPriollet B, Berthon PL and Cussenot O: Prostate carcinoma risk and allelic variants of genes involved in androgen biosynthesis and metabolism pathways. Cancer 92: 1130-1137, 2001.

32. Platz EA, Giovannucci E, Dahl DM, Krithivas K, Hennekens $\mathrm{CH}$, Brown M, et al: The androgen receptor gene GGN microsatellite and prostate cancer risk. Cancer Epidemiol Biomarkers Prev 7: 379-384, 1998.

33. Price DK, Chau CH, Till C, Goodman PJ, Baum CE, Ockers SB, et al: Androgen receptor CAG repeat length and association with prostate cancer risk: results from the prostate cancer prevention trial. J Urol 184: 2297-2302, 2010.

34. Nicolaiew N, Cancel-Tassin G, Azzouzi AR, Grand BL, Mangin P, Cormier L, et al: Association between estrogen and androgen receptor genes and prostate cancer risk. Eur J Endocrinol 160: 101-106, 2009.

35. Silva Neto B, Koff WJ, Biolchi V, Brenner C, Biolo KD, Spritzer PM and Brum IS: Polymorphic CAG and GGC repeat lengths in the androgen receptor gene and prostate cancer risk: analysis of a Brazilian population. Cancer Invest 26: 74-80, 2008.

36. Das K, Cheah PY, Lim PL, Zain YB, Stephanie FC, Zhao Y, et al: Shorter CAG repeats in androgen receptor and non-GG genotypes in prostate-specific antigen loci are associated with decreased risk of benign prostatic hyperplasia and prostate cancer. Cancer Lett 268: 340-347, 2008.

37. Lindström S, Zheng SL, Wiklund F, Jonsson BA, Adami HO, Balter KA, et al: Systematic replication study of reported genetic associations in prostate cancer: Strong support for genetic variation in the androgen pathway. Prostate 66: 1729-1743, 2006

38. Okugi H, Nakazato H, Matsui H, Ohtake N, Nakata S and Suzuki K:Association of the polymorphisms of genes involved in androgen metabolism and signaling pathways with familial prostate cancer risk in a Japanese population. Cancer Detect Prev 30: 262-268, 2006.

39. Krishnaswamy V, Kumarasamy T, Venkatesan V, Shroff S, Jayanth VR and Paul SF: South Indian men with reduced CAG repeat length in the androgen receptor gene have an increased risk of prostate cancer. J Hum Genet 51: 254-257, 2006.

40. Sieh W, Edwards KL, Fitzpatrick AL, Srinouanprachanh SL, Farin FM, Monks SA, et al. Genetic susceptibility to prostate cancer: Prostate-specific antigen and its interaction with the androgen receptor (United States). Cancer Causes Control 17: 187-197, 2006.

41. Salinas CA, Austin MA, Ostrander EO and Stanford JL: Polymorphisms in the androgen receptor and the prostatespecific antigen genes and prostate cancer risk. Prostate 65: $58-65,2005$.

42. Forrest MS, Edwards SM, Houlston R, Kote-Jarai Z, Key T, Allen $\mathrm{N}$, et al: Association between hormonal genetic polymorphisms and early-onset prostate cancer. Prostate Cancer Prostatic Dis 8: 95-102, 2005.

43. Mishra D, Thangaraj K, Mandhani A, Kumar A and Mittal R: Is reduced CAG repeat length in androgen receptor gene associated with risk of prostate cancer in Indian population? Clin Genet 68: 55-60, 2005.

44. Cicek MS, Conti DV, Curran A, Neville PJ, Paris PL, Casey G and Witte JS: Association of prostate cancer risk and aggressiveness to androgen pathway genes: SRD5A2, CYP17, and the AR. Prostate 59: 69-76, 2004.

45. Gilligan T, Manola J, Sartor O, Weinrich SP, Moul JW and Kantoff PW: Absence of a correlation of androgen receptor gene CAG repeat length and prostate cancer risk in an African-American population. Clin Prostate Cancer 3: 98-103, 2004.

46. Huang SP, Chou YH, Chang WS, Wu MT, Yu CC, Wu T, et al: Androgen receptor gene polymorphism and prostate cancer in Taiwan. J Formos Med Assoc 102: 680-686, 2003.

47. Gsur A, Preyer M, Haidinger G, Zidek T, Madersbacher S, Schatzl G, et al: Polymorphic CAG repeats in the androgen receptor gene, prostate-specific antigen polymorphism and prostate cancer risk. Carcinogenesis 23: 1647-1651, 2002. 
48. Mononen N, Ikonen T, Autio V, Rokman A, Matikainen MP, Tammela TL, et al: Androgen receptor CAG polymorphism and prostate cancer risk. Hum Genet 111: 166-171, 2002.

49. Balic I, Graham ST, Troyer DA, Higgins BA, Pollock BH, Johnson-Pais TL, et al: Androgen receptor length polymorphism associated with prostate cancer risk in Hispanic men. J Urol 168 : 2245-2248, 2002.

50. Modugno F, Weissfeld JL, Trump DL, Zmuda JM, Shea P, Cauley JA and Ferrell RE: Allelic variants of aromatase and the androgen and estrogen receptors: toward a multigenic model of prostate cancer risk. Clin Cancer Res 7: 3092-3096, 2001.

51. Xue W, Irvine RA, Yu MC, Ross RK, Coetzee GA and Ingles SA: Susceptibility to prostate cancer: interaction between genotypes at the androgen receptor and prostate-specific antigen loci. Cancer Res 60: 839-841, 2000.

52. Lange EM, Chen H, Brierley K, Livermore H, Wojno KJ, Langefeld CD, et al: The polymorphic exon 1 androgen receptor CAG repeat in men with a potential inherited predisposition to prostate cancer. Cancer Epidemiol Biomarkers Prev 9: 439-442, 2000.

53. Hsing AW, Gao YT, Wu G, Wang X, Deng J, Chen YL, et al: Polymorphic CAG and GGN repeat lengths in the androgen receptor gene and prostate cancer risk: a population-based case-control study in China. Cancer Res 60: 5111-5116, 2000.

54. Correa-Cerro L, Wohr G, Haussler J, Berthon P, Drelon E, Mangin P, et al: (CAG)nCAA and GGN repeats in the human androgen receptor gene are not associated with prostate cancer in a French-German population. Eur J Hum Genet 7: 357-362, 1999.

55. Edwards SM, Badzioch MD, Minter R, Hamoudi R, Collins N, Ardern-Jones A, et al: Androgen receptor polymorphisms: association with prostate cancer risk, relapse and overall survival. Int J Cancer 84: 458-465, 1999.

56. Ekman P, Gronberg H, MatsuyamaH,Kivineva M,Bergerheim US and $\mathrm{Li} \mathrm{C}$ : Links between genetic and environmental factors and prostate cancer risk. Prostate 39: 262-268, 1999.

57. Ingles SA, Ross RK, Yu MC, Irvine RA, La Pera G, Haile RW and Coetzee GA: Association of prostate cancer risk with genetic polymorphisms in vitamin $\mathrm{D}$ receptor and androgen receptor. J Natl Cancer Inst 89: 166-170, 1997.

58. Stanford JL, Just JJ, Gibbs M, Wicklund KG, Neal CL, Blumenstein BA and Ostrander EA: Polymorphic repeats in the androgen receptor gene: molecular markers of prostate cancer risk. Cancer Res 57: 1194-1198, 1997.

59. Li C, Gronberg H, Matsuyama H, Weber G, Nordenskjold M, Naito K, et al: Difference between Swedish and Japanese men in the association between AR CAG repeats and prostate cancer suggesting a susceptibility-modifying locus overlapping the androgen receptor gene. Int J Mol Med 11: 529-533, 2003.
60. Kuasne H, Rodrigues IS, Fuganti PE, Losi-Guembarovski R, Ito K, Kishima MO, et al: Polymorphisms in the AR and PSA genes as markers of susceptibility and aggressiveness in prostate cancer. Cancer Invest 28: 917-924, 2010.

61. Ashtiani ZO, Hasheminasab SM, Ayati M, Goulian BS and Modarressi MH: Are GSTM1, GSTT1 and CAG repeat length of androgen receptor gene polymorphisms associated with risk of prostate cancer in Iranian patients? Pathol Oncol Res 17: 269-275, 2011.

62. Akinloye O, Gromoll J and Simoni M: Variation in CAG and GGN repeat lengths and CAG/GGN haplotype in androgen receptor gene polymorphism and prostate carcinoma in Nigerians. Br J Biomed Sci 68: 138-142, 2011.

63. Chang BL, Zheng SL, Hawkins GA, Isaacs SD, Wiley KE, Turner A, et al: Polymorphic GGC repeats in the androgen receptor gene are associated with hereditary and sporadic prostate cancer risk. Hum Genet 110: 122-129, 2002.

64. Miller EA, Stanford JL, Hsu L, Noonan E and Ostrander EA Polymorphic repeats in the androgen receptor gene in high-risk sibships. Prostate 48: 200-205, 2001.

65. Irvine RA, Yu MC, Ross RK and Coetzee GA: The CAG and GGC microsatellites of the androgen receptor gene are in linkage disequilibrium in men with prostate cancer. Cancer Res 55: 1937-1940, 1995

66. Panz VR, Joffe BI, Spitz I, Lindenberg T, Farkas A and Haffejee M: Tandem CAG repeats of the androgen receptor gene and prostate cancer risk in black and white men. Endocrine 15: 213-216, 2001.

67. Mittal RD, Mishra DK, Thangaraj K, Singh R and Mandhani A: Is there an inter-relationship between prostate specific antigen, kallikrein-2 and androgen receptor gene polymorphisms with risk of prostate cancer in north Indian population? Steroids 72 : 335-341, 2007.

68. Santos ML, Sarkis AS, Nishimoto IN and Nagai MA: Androgen receptor CAG repeat polymorphism in prostate cancer from a Brazilian population. Cancer Detect Prev 27: 321-326, 2003.

69. Egger M, Davey Smith G, Schneider M and Minder C: Bias in meta-analysis detected by a simple, graphical test. BMJ 315: 629-634, 1997.

70. Begg CB and Mazumdar M: Operating characteristics of a rank correlation test for publication bias. Biometrics 50: 1088-1101, 1994.

71. Duval S and Tweedie R: Trim and fill: A simple funnel-plotbased method of testing and adjusting for publication bias in meta-analysis. Biometrics 56: 455-463, 2000 